\title{
Teacher Mobility in Punjab, Pakistan: Stayers and Movers within the Public and Private Schools
}

\author{
Nadia Siddiqui ${ }^{1, *}$ and Sadia Shaukat ${ }^{2}$ (D) \\ 1 Durham Evidence Centre for Education, School of Education, Durham University, Durham DH1 1TA, UK \\ 2 Faculty of Education, Bank Road Campus, University of Education, Lahore 54770, Punjab, Pakistan; \\ sadia.shaukat@ue.edu.pk \\ * Correspondence: nadia.siddiqui@durham.ac.uk
}

Citation: Siddiqui, N.; Shaukat, S. Teacher Mobility in Punjab, Pakistan: Stayers and Movers within the Public and Private Schools. Educ. Sci. 2021, 11, 358. https://doi.org/10.3390/ educsci11070358

Academic Editors: Beng Huat See, Rebecca Morris and Eila Jeronen

Received: 30 April 2021

Accepted: 13 July 2021

Published: 16 July 2021

Publisher's Note: MDPI stays neutral with regard to jurisdictional claims in published maps and institutional affiliations.

Copyright: (c) 2021 by the authors. Licensee MDPI, Basel, Switzerland. This article is an open access article distributed under the terms and conditions of the Creative Commons Attribution (CC BY) license (https:// creativecommons.org/licenses/by/ $4.0 /)$.

\begin{abstract}
Understanding the determinants of teacher mobility is important in order to implement effective policies for the recruitment, retention, and fair allocation of teachers. The teacher transfer policy implemented in Punjab, Pakistan, is intended to address corruption and a fair allocation of teachers in public schools. However, the policy has implications for teacher mobility. This paper presents survey findings on teacher mobility patterns in public schools in Punjab, Pakistan, examining the extent and determinants of mobility in comparison with teachers in private schools. In the survey, 1002 in-service teachers participated, and 46\% reported changing school at least once during their teaching career. The findings show that teachers who changed schools in their early career, with an average of two years of teaching experience, gained higher salary benefits by changing schools compared to experienced teachers, with an average of 14 years of teaching experience, who never changed schools. In comparison with early career teachers, experienced teachers who never changed school had lower salaries but higher satisfaction with life in general and with the school as their workplace. The most common reasons for changing school were lack of teaching resources, difficulty in commuting to school, unmanageable student-teacher ratio, and no chance of promotion in their teaching career. Teacher mobility was slightly higher in public schools compared to private schools, despite implementation of a merit-based transfer policy. A binary logistic regression model was constructed with the outcome of teacher mobility (or not), with a base figure of $54 \%$. By adding gender, marital status, school type, length of teaching experience, and teachers' satisfaction, the model increased correct predictions to $62 \%$. Teacher salary and teaching workload did not explain any variation in the model. These findings have implications for teacher transfer policy in public schools and lessons for private schools to retain teachers by offering longer contracts and reliable pension schemes. Policymakers must consider facilitating teachers' satisfaction with their workplace, particularly by making public schools in rural areas attractive places for the retention of teachers in early career phases.
\end{abstract}

Keywords: transfer policy; rationalisation; mobility; retention

\section{Introduction}

Teachers play an essential role in educational change and development [1]. In order to achieve children's universal access to primary and secondary education, all public schools are expected to have fair deployment and allocation of teachers. Governments cannot achieve the target of education for all without having teachers for all. The role of the teacher as a mediator of social and economic transformation has never been more evident than in the current times [2]. However, implications of meaningful teaching are increasing quickly in the contemporary world, and the criteria for education and learning are higher than ever before [3]. A standard of education is crucial for any country, and teacher education plays a significant role in regulating it. Since instruction is provided mostly by teachers, the size, alignment, and distribution of the teaching work force are significant factors for 
the effectiveness of public schools. Hence, public education is mainly the government's responsibility and is considered essential to the country's social and economic well-being and as well as its global competitiveness. Therefore, the appropriateness of the supply of teachers in relation to the demand and retention has been the substance of ongoing concern among teacher educators and policy makers accountable for certifying the efficiency of public schools [4].

This is a cross-sectional survey based on teacher mobility to understand patterns of teachers staying in or changing schools during their teaching career. All in-service teachers working in public and private schools in Punjab, Pakistan, were invited to complete a survey on job experience, their teaching career, and job mobility during their careers. In Punjab, public schools have a provincially centralised and merit-based transfer policy, while private and public-private partnership schools do not have a regular teacher recruitment system or transfer policy. The determinants of school job mobility might be different across the two sectors. Salary, nature of job contracts, transfer policies, student-teacher ratio, workload, and satisfaction with work environment can contribute to teachers' decisions of changing schools which in turn has implications on teacher retention, teacher shortage in disadvantaged regions, and compositional disparities in teaching quality.

This survey study shows teacher mobility is slightly higher in public schools compared with private schools, despite after a successful implementation of rationalization and merit-based transfer policies. The rationalization policy introduced in Punjab was intended to make teacher deployment and transfer free from corruption, improve teacher retention, and equalise teacher composition in urban and rural schools. The policy has tackled corruption to some extent, but the implementation has not successfully met the targets of fair allocation of teachers. Teachers have shown dissatisfaction with their job placements, and this is associated with teacher mobility within the public schools. Schools in socioeconomically disadvantaged areas particularly located in remote and rural locations have vacant positions, which is a sign of teacher shortage. However, schools in central urban locations have surplus teachers.

A social media campaign by a large number of public school teachers protested against the impact of transfers on their lives. Female teachers protested against transfer orders and deployment to hard-to-reach areas, which had practical implications on travelling to schools in distant locations, as it is financially unaffordable, unsafe for travelling alone, and time consuming. It is perhaps the implementation of rationalisation and transfer policy that has made teacher mobility more volatile in public schools compared with private schools. The findings of this survey study show that higher salaries and time allocated for workload are not related to the teachers' decision to change schools; instead, an important factor that retains teachers is their satisfaction with work environment. The findings of this survey have to be treated with caution due to the voluntary and unrepresentative sample, but they provide an insight into the possible association between teacher retention and working environment.

\section{Background}

The school teacher workforce in Pakistan is divided into public and private sectors. According to Pakistan Education Statistics (2018-2019), public schools have more student proportion ( 29 million) as compared to the private schools (21 million) [5]. Teacher workforce is slightly higher in private schools $(51 \%)$ when compared with teachers in public schools (49\%). Although public schools have a larger student population when compared with private schools, the public sector has a shortage of teachers. Teacher training or licenses for working in a school are not compulsory requirements in public or private schools. Therefore, anyone can apply for a school teaching job. There could be several reasons for the imbalance in teacher workforce distribution in the systems, which run parallel but independent of each other [6]. Fixed-term and permanent contracts, salary, pensions, and privileges are very different across the two systems [7]. Each of the four provincial governments have independent but centralised merit-based systems for teacher 
recruitment, deployment, promotion, and job transfer. Private schools exist in all four of the provinces and are independent in recruiting teachers and implementing policies to meet their needs of teaching workforce [8].

In this paper, we are presenting the case of Punjab in Pakistan, where in the last ten years several public school education policies and initiatives have been implemented to address corruption in education and fairly manage teacher workforce.

In 2016, the School Education Department (SED) in Punjab introduced standardised test-based performance measures for selecting public school teachers on permanent positions. In addition to setting standards of selection in the teacher recruitment and deployment process, the provincial government implemented new policies for a fair distribution of teachers in public schools. There were also concerns regarding teacher shortages in rural and geographically remote areas, exasperated by the corruption in the process of teacher transfers in public schools. Teacher transfers were managed through manual applications. Bribery, nepotism, and contacts in the public offices made teacher deployment and transfer less transparent, more unfair, and a longer process $[9,10]$.

In 2013, the education minister in Punjab implemented teacher transfer policy on a point-based system [5]. The criteria currently in practice include: Distance (more than $8 \mathrm{~km}$ from home are eligible) (20 points), years of service (30 points), seniority ( 20 points) (teachers in first 3 years of service cannot apply), wedlock basis (15 points), and compassionate grounds (15 points).

Rationalisation measures were introduced in public school of Punjab in 2010 where surplus teachers in schools were re-allocated when there was a teacher shortage. The student-teacher ratio was introduced where 1 teacher for 40 students was an agreed ratio at primary school level. This is a high student-teacher ratio when compared to countries with similar education contexts such as Morocco, Tunisia, and Turkey [10]. In the policy documents, there is a lack of clarity in how rationalisation of teachers in public schools is conceptualised in a centrally managed system of teacher recruitment and deployment. Theoretically, there is no need to have a transfer policy if the system is centrally managed because demand for teachers is fulfilled by the teacher recruitment system when there is a need. However, the school systems are dynamic due to factors such as changes in student population, teachers completing service period, changes in circumstances of teachers' life, schools merging or closing, and most importantly teachers as permanent public employees have protected right to work, salary, and pensions [10]. Closure of any public school means that the teachers during their service period need to be reallocated if they become redundant or a surplus. However, there is no promising evidence on existing policies which has fairly and equitably managed teacher deployment or transfer.

Teachers in the public schools can now apply for transfers to another school of their choice within a district. All transfer applications are managed through E-transfer process which is part of the digitalisation initiative introduced in 2018. An internet-based application system has made the process accessible and transparent. Depending on the points gained on the given set of criteria, the transfer application is accepted or rejected. Nearly 100,000 teachers applied for the transfer, and 50,000 were accepted [7]. Applications for public school transfers are accepted if their choice of school meets the criteria of rationalization. There are less chances of corruption involved in the process. However, this has not addressed teacher shortages in disadvantaged areas.

Public school teachers can apply for promotions when there is a vacancy available that offers an upscale in teaching position. This is a transfer by promotion to other school in the same district. These transfers are based on seniority level in the period of service, which means if more than one teacher applies for a vacancy, then the senior applicant would have more chances of acceptance. Transfer by promotion favours experienced teachers. SED, Punjab, Pakistan, has maintained administrative data of teacher transfer, transfer decisions, and promotions can show patterns, the extent, and direction of mobility in rural and urban regions. The existing international evidence based on administrative datasets shows that teacher mobility by seniority level adversely affects the quality of teaching in schools and 
mainly impact disadvantaged students' learning experience who are concentrated in the regions of high socioeconomic poverty [8].

In a centrally managed system, public school teachers have a condition-based choice to change schools, whereas private school teachers can leave and join any private school where there is a vacant position subject to acceptance of the application by the headteacher or school management system. These two systems attract a large number of teacher workforce, but differences in policies have implications on who join and retain in teaching career, leading to subsequent outcomes such as teachers' satisfaction with their work environment with their salary $[9,10]$ and passion for teaching profession [11]. Teachers make choice to leave, stay or move within public and private system. There is no evidence of teacher exchange or crossover in the two sectors, and perhaps, this is related with differences in policies for teacher recruitment, deployment, salary structure, school environment, and pension schemes [12].

In the public sector, higher salaries and permanent job positions show higher rates of teacher's attendance in comparison with teachers on lower salaries and shorter job contracts [13]. It is well known that teachers are less likely to remain on a long-term basis in private schools. This phenomenon of hiring teachers on short-term contracts is well described by the analogy of 'schools as sausage machines' where teachers work on short-term contracts and are hired and fired on demand basis [14]. In context of Punjab, Pakistan, administrative large-scale data are required to understand differences in the teacher workforce across the public and private schools. The determinants of teacher mobility within the systems are unclear, and there is no sufficient evidence if the government policies such as rationalisation and teacher transfer are appropriately targeting the underlying issues of teacher job mobility in Pakistan. This study answers the following questions:

- Are teachers who stay in school different from teachers who change schools?

- What factors determine teachers' job mobility?

SED, Punjab has made several improvements in digitalisation of school and student data introducing new regulations for public school teachers so that they can apply for transfer under the new merit-based policy. Teachers can also challenge their transfer orders using the same system. The SED has large amounts of data on teacher supply, deployment, transfer, and promotions, but access to this valuable information is not available for independent research use. Unfortunately, we were not successful in our request to the department in achieving these data, which could be the most appropriate for answering research questions on teacher school mobility, at least in the public school sector. We launched an online survey to collect self-reported information on teachers' job satisfaction, workload, and school mobility during their teaching career. The online teacher survey included in-service teachers from private and public school sectors.

We investigated mobility of teachers within public and private school system in schools of Punjab. All in-service teachers were invited to complete an online survey. Punjab public schools have a centralised and merit-based transfer policy, while private and public-private partnership schools do not have a regular teacher recruitment and teacher transfer policy. Considering the differences, the hypothesis in this research was that the teacher job mobility would be less prevalent in public schools when compared with teachers in private schools. Salary, student-teacher ratio, workload, and satisfaction with work environment contribute to teachers' decisions to change schools. The existing evidence based on non-random selection of teacher's interviews has shown that teachers on short-term contracts in private schools are more mobile than teachers on permanent contracts in public schools [15].

This study presents survey findings on teacher workforce differences between two different school systems and analyse the factors that determine teacher school mobility (or lack of it) in their teaching career. 


\section{Existing Evidence on Teacher Mobility}

Teacher supply and mobility have important links to the effective delivery of education. There is international research evidence on effective school mechanisms which shows teachers' stability, consistent professional development, and satisfaction with school play important role in efficient working of school [16]. There is no clear evidence regarding teacher supply mechanism and determinants of teacher mobility in context of Pakistan. This is a complex school education sector in which teacher supply/demand and mobility could have multiple determinants and can lead to various school level outcomes. The knowledge of the factors that drive teachers' recruitment, supply to schools, and mobility during different phases of teaching career can inform effective policy measures in which interest of various stakeholders can be protected.

There is a concern over the influence of teacher job change on both the inclusive level of teacher quality and the supply of teacher quality across schools [17]. Teachers leaving the profession or switching schools located in economically developed regions lead to compositional disparities in terms of teacher quality $[18,19]$. This has implications on designing feasible policies that can support sustainable school systems, where teacher retention in their prime years of teaching career and experience can benefit student accomplishment [20]. There is an indication that within-profession teacher mobility is contributing some variation in terms of teacher's credentials [21].

Teachers working in schools with a higher proportion of disadvantaged students are more likely to transfer to a new school district [22], and teachers in municipal inner-city schools are more likely to transfer away from their schools than teachers in other areas [23]. Another factor is the efficiency of a teacher relative to their peer teachers may impact teacher job choice, though the direction of the effect is uncertain. Teachers tend to seek out positions where their efficiency matches with the efficiency of their peers. In addition, productive teachers tend to choose those schools where their work compatibility and intellectual interest align with their peer teachers to enhance their intellectual growth and professional development [24]. On the other side, there is some evidence that ambitious and qualified teachers might choose to transfer to schools where the work environment does not demand work efficiency and high-performance goals to achieve [25].

Through the existing period of educational reform beginning in the early 1980s, the teaching force has been extensively considered, on the whole, as insufficient to encounter current national supplies [26,27]. Meaningful teaching delivered effectively by trained and highly competent teachers have a high demand in all education systems [28]. Therefore, the equitable supply of teachers in relation to the demand and retention has been an important concern for policymakers who are accountable for the efficiency of public schools [29].

Many recent reports by blue ribbon commissions have determined that education as a whole, and teachers in actuality, are not producing government school students with the level of knowledge, skill, and discipline required in today's multifaceted and competitive economic environment [30]. Teachers who live farther from school tend to remain more absent; particularly, female teachers are more absent and are less likely to have access to safe transport facility. Teachers are expected to perform tasks that have no direct relevance with children's learning. The education department assign orders to teachers for completing nonteaching duties such as helping with antipolio and antidengue drives, election duties, and administering government exams and conducting surveys. A study conducted by Alif Ailaan and SAHE assessed that government teachers spend a quarter of the academic year on nonteaching activities that can contribute to weakening the performance of school students [31].

The government has introduced initiatives to monitor presence and work performance of the teachers in the classrooms, in response to a long-term problem of teacher absenteeism [32]. There have been initiatives implemented for the least number of improvements in public school quality such as addressing teacher absenteeism. All public school teachers now mark biometric attendance [33], and there are also uninformed inspection visits. These changes implemented in Punjab have made teachers to be compliant and present in 
school during expected job hours. However, teacher unions have raised their voice about the time for teaching or preparation for teaching have been increasingly replaced with teachers' involvement in administrative and managerial tasks. Teaching workload and administrative duties such as participation children's enrolment drives, campaigns for the eradication of polio, dengue, and Covid-19 has led to burnout [34]. Teachers in private schools have no involvement in government-led campaigns; therefore, their allocated time is entirely dedicated for teaching-related activities.

Another reason of teacher mobility is the geographical context and school characteristics. Geographical preferences are overall relatively personal, being related to ignored individual preferences; teachers have to take up whatever the location is presented to them and quite often commence their careers distant from their preferred physical location. This obviously affects the efficacy of teachers and of the education system as a whole. Discontented teachers may be poor performers, not only because of overall motivational factors [35] but also since they are merely waiting to move on to a diverse location, exerting low effort into their existing work duties and ignoring any extended term plans for their students [36]. Schools' characteristics such as size of classroom, infrastructure, and being under-resourced contribute to teacher mobility [37].

Teaching experience can be challenging in schools where students and parents depend on additional and constant support from school and teachers. Teachers try to avoid schools situated in a setting with a high poverty rate and a high percentage of people working in agriculture. Moreover, in schools with a higher portion of disabled students, drop-out students, and students failing to gain admission to the next grade make such schools less attractive to teachers [37].

Considering the aforementioned determinants of teacher mobility, Punjab SED initiated E-transfer policy to apply school transfer online and to avoid visiting the School Education Department physically. Government statistics reflecting main shortages in the quantity of teachers in public schools, it is generally perceived that the education system is failing as a result of deficiencies in both the quantity and quality of teachers [38].

Teachers in public schools are always at the good will of school education department and school administration. Transfer policy for rationalisation has been the reason of distress among teachers in public schools. A social media campaign against these new regulations led to a protest in Punjab [39,40].

There has been some evidence that a regular transfer of teachers generates not only conflicts for the teachers, their families, and children but also affect the quality of teaching and learning in the schools [41]. There are no accommodation facilities or additional transport allowance for teachers placed in remote areas. Lack of capacity building opportunities has also shown association with teachers' dissatisfaction with the teaching profession [42,43].

Teachers' decisions to change school or leave the teaching profession can be determined by workload stress and nature of tasks in the teaching duties. Existing studies have shown that workload-related stress and number of hours spent on teaching tasks, such as marking, are associated with teachers' declining quality of life [44].

\section{Research Design and Methods for Analysis}

This study is a survey-based cross-sectional research design in which respondents volunteered to take part and self-reported their information. An online survey was developed for in-service teachers' participation. The survey language was English because all in service can read, understand, and respond in this language. The online survey link was widely distributed in schools and social media forums for teachers' high response rate. The survey message invited teachers for volunteering participation and sharing information for the purpose of research. There was no sensitive information collected that could potentially harm or breach the confidentiality of the respondents. No rule was set on questions; therefore, respondents could skip giving any information which they did not like to share. Only one question required a compulsory response, which asked all the 
respondents to report in 'yes' or 'no', if they had ever changed school during their teaching career. The survey completion time for each respondent was less than $10 \mathrm{~min}$.

The survey included three main sections on general life and job satisfaction, teaching workload, and reasons for changing school. General life and job satisfaction and teaching workload sections were for all respondents. The third section on reasons for changing schools was only available for those respondents who reported that they changed school at least once in their teaching career. Items in all sections were statements to be rated on scale of $0-10$ where 0 means 'not at all' and 10 means 'a lot'. The analysis is based on averages and standard deviations of the rated items, which are then used for calculating the effect size.

At the end of each section, there was an open dialogue box for respondents to give any additional information or explanation of responses they wanted to contribute. The item response-scale was consistent in all sections except for the background information. Teachers' self-reported information on age, marital status, work experience, type of school they worked, and take-home salary, which were open-response items or multiple answer choice.

This survey invited volunteering participants, and in order to retain a large sample with minimum dropout, we did not set a compulsory rule in question items except for one. This resulted in missing data, which we coded as missing. We did not replace missing responses with weighted values or used any methods for statistical imputations.

Simple descriptive and bivariate analysis demonstrated the difference between two groups of teachers who changed school and those who never changed school. For each item mean score and standard deviation were used to calculate the effect sizes, which measure the magnitude of the difference in the responses between the two groups.

To identify the determining factors or predictors in explaining the differences the two groups, a binary logistic regression analysis was performed. The binary outcome variable was 'changed' school or not, and other variables were introduced as predictors using a stepwise forward analysis. This means predictor variables, which were not contributing any explanation in the variation (percentage correctness) were removed.

The obtained sample from online survey naturally included $46 \%$ of teachers who changed school and $54 \%$ of those who never changed school. This is an appropriate balance in the overall distribution of the sample, thereby meeting the condition for binary logistics analysis [45]. This distribution means before adding any explanatory variable in the regression model, there is nearly $54 \%$ chance that any case would change a school. By adding predictor variables such as gender, age, work experience, satisfaction with job, workload, take-home salary, school type, etc. We anticipated an increase in the percentage correctness or likelihood of cases to be accurately predicted. The results of regression analysis showed major determinants of teacher mobility and those, which need more focus in policy for teacher recruitment, deployment, and retention.

\section{Teachers Who Participated in the Study}

This survey is opt-in participation of in-service teachers. This means teachers volunteered to take part in the survey in response to our invitation sent to nearly 680 schools in Punjab. We also used our social networks and personal links in approaching school education forums and groups inviting teachers to take part in the study. It is hard to estimate a response rate because the information was widely shared, but a large number of teachers volunteered to take part in the online survey. However, the online survey is restricted to only those who have access to internet technology to receive the information and complete the survey. The nonrandom sample of 1002 teachers does not represent teacher population of the time in Punjab, Pakistan. However, it is large enough in each category of characteristics to conduct a meaningful analysis. The sample is reasonably large for meaningful calculations of effect sizes and regression modelling (see more details in [45]). Table 1 shows characteristics of the achieved sample. 
Table 1. Percentage of teachers.

\begin{tabular}{|c|c|}
\hline & Percentage \\
\hline \multicolumn{2}{|l|}{ School type } \\
\hline Public & 54 \\
\hline Private & 29 \\
\hline Public-Private Partnership & 16 \\
\hline Madrassah & 1 \\
\hline \multicolumn{2}{|l|}{ Gender } \\
\hline Male & 35 \\
\hline Female & 65 \\
\hline \multicolumn{2}{|l|}{ Geographical region } \\
\hline Urban & 51 \\
\hline Rural & 47 \\
\hline Missing & 2 \\
\hline \multicolumn{2}{|l|}{ Marital status } \\
\hline Married & 54 \\
\hline Single & 43 \\
\hline Missing & 3 \\
\hline \multicolumn{2}{|l|}{ Highest Qualification } \\
\hline Completed diploma & 3 \\
\hline Completed higher education (Graduate level and above) & 88 \\
\hline Completed intermediate studies & 6 \\
\hline Completed secondary & 3 \\
\hline Missing & 1 \\
\hline Take home salary self-reported & 95 \\
\hline Teaching experience self-reported & 97 \\
\hline Age in years self-reported & 97 \\
\hline Total & 1002 \\
\hline
\end{tabular}

According to Table 1 the sample has a higher participation of female teachers from public schools in urban areas. The majority of teachers have completed higher-education studies. These are very similar with official figures on teacher workforce in Punjab.

Cases with missing information are retained as much as possible instead of excluding them from analysis. Teachers self-reported their background characteristics, salary, age, and work experience in years. These are important indicators to understand the patterns of school job mobility in teaching career.

Table 2 shows the gender pay gap in teaching workforce. On average, public school teachers earn higher salary than teachers in private and public-private partnership schools. This means public school teachers are advantaged over other teachers by having permanent and pensionable jobs with higher salaries. This is consistent with the evidence on public and private salary differences presented in study called Learning and Educational Achievement in Punjab Schools [43]. Teaching experience in years is also highest for teachers in public school, which could be due to working on permanent job contracts. Private schools offer higher salaries when they recruit teachers, but not many offer pension or benefits, therefore being less likely to retain teachers on a long-term basis. 
Table 2. Average teacher salary and work experience.

\begin{tabular}{ccc}
\hline & Take Home Salary (Average) & $\begin{array}{c}\text { Work Experience in Years } \\
\text { (Average) }\end{array}$ \\
\hline Male & Rs 39,455 & 9 \\
\hline Female & Rs 27,472 & 8 \\
\hline Urban & Rs 34,129 & 8 \\
\hline Rural & Rs 29,191 & 8 \\
\hline Public & Rs 40,119 & 11 \\
\hline Private & Rs 22,034 & 5 \\
\hline Public-Private Partnership & Rs 19,050 & 6 \\
\hline Madrassah & Rs 15,000 & 5 \\
\hline
\end{tabular}

\section{Who Changed Schools in Their Teaching Career?}

In this online survey, 1002 in-service teachers participated and self-reported their responses and background information. The descriptive analysis shows differences in teachers' background characteristics for those who changed schools and those who never changed school (See Table 3).

Table 3. Percentage who changed/never changed school.

\begin{tabular}{|c|c|c|}
\hline & Changed School \% & Never Changed School \% \\
\hline \multicolumn{3}{|l|}{ School type } \\
\hline Public & 50 & 50 \\
\hline Private & 46 & 54 \\
\hline Public-private partnership & 34 & 66 \\
\hline Madrassah & 33 & 67 \\
\hline \multicolumn{3}{|l|}{ Gender } \\
\hline Male & 45 & 55 \\
\hline Female & 47 & 53 \\
\hline \multicolumn{3}{|l|}{ Geographical region } \\
\hline Urban & 48 & 52 \\
\hline Rural & 45 & 55 \\
\hline \multicolumn{3}{|l|}{ Marital status } \\
\hline Married & 54 & 47 \\
\hline Single & 39 & 61 \\
\hline \multicolumn{3}{|l|}{ Highest Qualification } \\
\hline Completed diploma & 29 & 71 \\
\hline Completed higher education & 47 & 53 \\
\hline Completed intermediate studies & 39 & 61 \\
\hline Completed secondary & 47 & 53 \\
\hline Take home salary (average) & Rs.31,197 & Rs. 24,988 \\
\hline $\begin{array}{c}\text { Teaching experience in years } \\
\text { (average) }\end{array}$ & 2 years & 14 years \\
\hline Age in years (average) & 34 & 55 \\
\hline Total & 540 & 462 \\
\hline
\end{tabular}


Teacher mobility in public schools is slightly higher as compared with private schools. Half of the public school teachers have changed school at least once in their teaching career despite permanent teaching positions, and job transfer is a competitive point-based merit system. There are some other slight differences such as teachers in urban areas changing schools more than teachers in rural areas. Urban areas have more schools and therefore more job opportunities as compared to rural areas. The direction of teacher transfer could be more likely from rural to urban location. Vacant teaching positions in rural schools might offer promotion opportunities, but teachers working in urban school locations would prefer not to transfer to the vacant positions in rural areas due to general lack of resources. More female teachers change schools than male teachers, which could be associated with change in marital status where female teachers are more likely to migrate.

Average salary and years of teaching experience show bigger gaps. Experienced teachers have served in a school for a long time and never changed schools, while teachers in early careers changed schools within two years. On average, teachers' retention in a school on long-term basis does not show association with salary because less experienced teachers who changed schools within average of two years in teaching careers are earning extra Rs 6208. A possible explanation of this difference could be that teachers stay in a school on long-term basis if they are satisfied with their job and school environment, while salary is not a compelling factor to change school. Teachers change school if they are not satisfied with their job and school environment, and joining a new school would mean negotiating and accepting only a higher salary than what they were receiving previously. Public and private salary structures could also be related with these gaps. Regression analysis shows if difference in the mobility patterns can be explained by teachers' satisfaction, workload, salary, and school type or not.

Table 4 shows differences in life and job satisfaction of teachers in public, private, and private-public partnership schools. The differences are reported as effect sizes interpreted as standardised gap between teachers who changed schools at least once in their teaching career and those who never changed school. The effect sizes are separately reported for the school types to show differences in the patterns of teacher mobility more clearly. Highlighted items show noticeable differences.

The overall effect sizes in Table 4 show that teachers who changed school are less satisfied with their life and work experience at school as the effect sizes are consistently negative. Work environment, work-life balance, and assistance in teaching activities have large negative effect sizes. These effect sizes are about their current job experiences in schools where they moved to and were currently working when they completed the survey. It is surprising to see that changing schools does not make any positive difference to their life and job satisfaction. Those who never changed schools are more satisfied with life and work environment in their current school. This is an indication that teacher retention is higher when the work environment has a sufficient amount of support available for teachers and they have a good work-life balance. Public schools have the option of promotion by transferring to other schools where there are vacant positions. However, it might be that public school teachers do not want promotion by transferring to schools where they have to compromise on work environment. These are likely to be schools in rural areas where limited resources can make teachers feel isolated from developed regions and losing development opportunities available in urban regions.

The effect sizes were calculated for the public and private schools, and there is no big difference in these two school types except large negative gaps in two categories of satisfaction: life in general and availability of time in personal life. Public school teachers who changed schools were less satisfied in life in general and have less availability of time in personal life than their counterpart in private schools. This is perhaps associated with rationalisation of teachers when surplus teachers in a school are transferred to schools against their choice. Teacher shortage in rural areas can also increase the workload for teachers in rural regions. 
Table 4. Effect size/Life satisfaction/Changed school/Never changed schools.

\begin{tabular}{|c|c|c|c|}
\hline Life Satisfaction & All & Public & $\begin{array}{l}\text { Private and } \\
\text { Public-Private } \\
\text { Partnership }\end{array}$ \\
\hline Generally, I am satisfied with my life & -0.03 & -0.15 & -0.01 \\
\hline I feel happy most of the time & -0.07 & -0.05 & -0.01 \\
\hline $\begin{array}{l}\text { I have plenty of time to do the things I want in } \\
\text { personal life }\end{array}$ & -0.18 & -0.12 & 0.00 \\
\hline I get excited about teaching & -0.03 & -0.10 & 0.02 \\
\hline I enjoy working with students & 0.06 & -0.08 & 0.02 \\
\hline I like the work environment of my school & -0.17 & 0.03 & -0.03 \\
\hline It is convenient to commute to school regularly & -0.15 & -0.08 & -0.01 \\
\hline $\begin{array}{l}\text { I am satisfied with the student-teacher ratio in } \\
\text { my school }\end{array}$ & -0.13 & -0.01 & 0.00 \\
\hline I enjoy working with my colleagues & -0.08 & -0.07 & -0.01 \\
\hline I am satisfied with my current salary package & -0.05 & -0.06 & -0.03 \\
\hline $\begin{array}{l}\text { I achieve a good balance between my work life } \\
\text { and my private life }\end{array}$ & -0.21 & -0.05 & -0.06 \\
\hline $\begin{array}{l}\text { I can complete my assigned teaching workload } \\
\text { during contracted working hours }\end{array}$ & -0.15 & -0.09 & -0.01 \\
\hline $\begin{array}{l}\text { I work on my teaching duties during weekends } \\
\text { and holidays }\end{array}$ & -0.14 & -0.12 & 0.05 \\
\hline $\begin{array}{l}\text { The school has provided me teaching assistance } \\
\text { (e.g., helper staff, computer/laptop, etc.) to } \\
\text { support my teaching activities }\end{array}$ & -0.21 & -0.08 & -0.02 \\
\hline $\begin{array}{l}\text { I can quit teaching if I get some other source } \\
\text { of income }\end{array}$ & -0.05 & -0.10 & 0.00 \\
\hline I want to work in another school & 0.10 & -0.07 & 0.04 \\
\hline Total & 1002 & 544 & 449 \\
\hline
\end{tabular}

Time allocation for work-related activities can contribute to overall work experience and satisfaction with teaching job. Table 5 shows the effect sizes of mobile teacher time allocation in workload for activities that can support their teaching. The negative effect sizes show that teacher who changed schools have shown less amount of time allocated to their teaching activities. The items are highlighted where effect sizes are large for consideration. In these highlighted items, there is an underlying need for support and professional growth, which is neglected in the workload model. Time for mentoring, peer feedback, and training for development are not available in workload, which can make overall teaching experience less supported with appropriate measures.

Table 5 on workload time allocation, there are slight but consistent negative effect sizes for those who changed schools within public and private system. Although teachers in public schools have reported having less time to do things in their personal lives, the effect sizes in Table 5 show they have more time allocated in workload for teaching activities and teaching support when compared with teachers in public school. Mobile teachers in private school work slightly more than their allocated time, but these effect sizes are very small to make any definitive conclusions. 
Table 5. Effect size/Time allocated for the workload/Changed school/Never changed schools.

\begin{tabular}{cccc}
\hline Workload & Effect Size All & Public & $\begin{array}{c}\text { Private and } \\
\text { Public-Private } \\
\text { Partnership }\end{array}$ \\
\hline $\begin{array}{c}\text { Marking students' work } \\
\text { counselling }\end{array}$ & -0.16 & 0.07 & -0.11 \\
\hline $\begin{array}{c}\text { Individual student time for } \\
\text { Preparation for lessons }\end{array}$ & -0.15 & 0.00 & -0.08 \\
\hline Mentoring other teachers/colleagues & -0.13 & 0.03 & -0.08 \\
\hline Breaks for lunch/ short period of rest & -0.10 & 0.05 & -0.06 \\
\hline $\begin{array}{c}\text { Observe other teachers for feedback } \\
\text { and/or learning practice }\end{array}$ & -0.14 & 0.03 & -0.05 \\
\hline $\begin{array}{c}\text { Being mentored by } \\
\text { teachers/ colleagues }\end{array}$ & -0.18 & 0.05 & -0.09 \\
\hline Parent teacher meeting & -0.13 & 0.03 & -0.05 \\
\hline $\begin{array}{c}\text { Professional development training } \\
\text { Participation in the civic campaigns } \\
\text { such as information on Dengue, } \\
\text { Corona, etc, }\end{array}$ & -0.18 & -0.02 & -0.05 \\
\hline $\begin{array}{c}\text { To be involved in the National Day, } \\
\text { Kashmir Day, Election officer and } \\
\text { different rallies }\end{array}$ & -0.07 & 0.07 & -0.05 \\
\hline $\begin{array}{c}\text { To be involved in board exam duty as } \\
\text { invigilator or exam marker }\end{array}$ & -0.04 & 0.02 & -0.08 \\
\hline Total & 1002 & 544 & -0.09 \\
\hline \begin{tabular}{c} 
Ton \\
\hline
\end{tabular} & & 0.03 & 449 \\
\hline
\end{tabular}

\section{Determinants of Teacher Mobility}

Binary logistic regression model was constructed with an outcome variable of changed school or not. The obtained sample from online survey naturally included $46 \%$ of teachers who changed school and $54 \%$ of those who never changed school. This is an appropriate balance in the overall distribution of the sample and therefore meets the condition for binary logistics analysis [44]. This distribution means before adding any explanatory variable in the regression model, there is nearly $54 \%$ chance that any case would change a school. By adding predictor variables such as gender, age, work experience, satisfaction with job, workload, take-home salary, school type, etc., we anticipated an increase in the percentage correctness or likelihood of cases to be accurately predicted.

Table 6 shows that after introducing teacher background details, the percentage correctness of the model increased by $8 \%$ points. This means that there is still a high percentage of $38 \%$ which remains unexplained. It could be due to limitation in the sample and data quality. However, the known predictors have shown some interesting patterns. The constructed model individually excluded the variables to observe changes in the percentage correctness. Upon exclusion of age, take-home salary, and time for workload did not change the percentage correctness. This could mean that teacher mobility is not determined by these variables. 
Table 6. Binary logistic model changed (Changed school/Never changed schools).

\begin{tabular}{|c|c|c|c|c|c|}
\hline & & & \multicolumn{3}{|c|}{ Predicted } \\
\hline & & & \multicolumn{2}{|c|}{$\begin{array}{l}\text { Have you changed school(s) } \\
\text { during your teaching career? }\end{array}$} & \multirow{2}{*}{ Percentage Correct } \\
\hline & & & No & Yes & \\
\hline \multirow{3}{*}{ Step 0} & \multirow{2}{*}{$\begin{array}{l}\text { Have you changed school(s) } \\
\text { during your teaching career? }\end{array}$} & No & 540 & 0 & 100.0 \\
\hline & & Yes & 462 & 0 & 0.0 \\
\hline & \multicolumn{2}{|c|}{ Overall Percentage } & & & 53.9 \\
\hline Step 1 & \multicolumn{2}{|c|}{$\begin{array}{l}\text { School type, sex, region, marital status, }{ }^{*} \text { age, work } \\
\text { experience, }{ }^{*} \text { Take-home salary, satisfaction with life } \\
\text { and work, * time for workload }\end{array}$} & & & 62 \\
\hline
\end{tabular}

* Do not change percentage correctness if excluded from the model.

Table 7 shows coefficient in the odds ratio of the predictors added in the model. This represents the likelihood of teacher mobility by controlling the predictors.

Table 7. Binary logistic model predicting outcome Changed school/Never changed schools.

\begin{tabular}{cc}
\hline Predictors & Odds Ratio \\
\hline Are you? Female vs. Male & 1.30 \\
\hline Geographical region Rural vs. Urban & 0.97 \\
\hline What is your marital status? Married vs. Single & 1.44 \\
\hline Work experience in years & 1.04 \\
\hline Take-home salary & 1.00 \\
\hline School Types vs. Public & 1.15 \\
\hline School Type (Madrassah) & 0.80 \\
\hline School Type (Private) & 1.43 \\
\hline School Type (Public-Private Partnership) & 0.98 \\
\hline Satisfaction average & 1.07 \\
\hline Time for workload &
\end{tabular}

The coefficients are in the odds ratio, meaning that, all other things taken into account so far, a female respondent in the category of sex is 1.30 times more likely to change the school than male counterpart. Odds of 1 would mean likely to change schools. The negative odds are $\leq 0$ and are interpreted in percentage. Teachers in private schools are less likely to change schools. The odds ratio of 0.80 means that private school teachers would likely to be in $20 \%$ chance of changing school in comparison with public school teachers. Teachers in urban areas are more mobile than teachers in rural areas.

Age and teaching experience made no difference in the percentage correctness and were excluded from the mode; therefore, the coefficients for only work experience are included. Teachers in early career stages (experienced less than 2 years) are more mobile than older teachers, but mobility seems less explained by experience. Teacher satisfaction and time for workload are average scores rather than categorical values. Teachers less satisfied with work environment are more likely to change schools than those who reported higher satisfaction. Teachers who have less time allocation in workload are more likely to change schools. 


\section{Why Change Schools?}

Teachers who reported changing jobs were asked to rate separate set of items on the scale of $0-10$ indicating the reasons of changing schools. This section included $34 \%$ of the teacher sample.

Table 8 show effect size differences for public school teachers in comparison with private school teachers.

Table 8. Reasons for job mobility on scale of 0-10. Public vs. Private and Public-Private partnership.

\begin{tabular}{|c|c|c|c|}
\hline & Public & $\begin{array}{l}\text { Private and Public-Private } \\
\text { Partnership }\end{array}$ & Effect Size \\
\hline $\begin{array}{l}\text { I never wanted to change my teaching job } \\
\text { to another school }\end{array}$ & 4.58 & 4.50 & 0.02 \\
\hline $\begin{array}{l}\text { I was transferred by the education } \\
\text { authorities }\end{array}$ & 4.88 & 3.41 & 0.35 \\
\hline $\begin{array}{l}\text { I was offered a better salary in another } \\
\text { school }\end{array}$ & 2.30 & 5.83 & -0.86 \\
\hline $\begin{array}{l}\text { In the previous school my workload was } \\
\text { more than my monthly salary }\end{array}$ & 3.13 & 6.32 & -0.78 \\
\hline $\begin{array}{l}\text { In the previous schools, working hour } \\
\text { policy was not feasible }\end{array}$ & 2.56 & 5.34 & -0.71 \\
\hline $\begin{array}{l}\text { My job contract was not renewed by the } \\
\text { previous school }\end{array}$ & 2.00 & 4.06 & -0.53 \\
\hline $\begin{array}{l}\text { I was offered a permanent/longer contract } \\
\text { by another school }\end{array}$ & 2.51 & 4.40 & -0.46 \\
\hline $\begin{array}{l}\text { It was difficult to commute to previous } \\
\text { school regularly }\end{array}$ & 3.52 & 4.54 & -0.25 \\
\hline The new school offered a transport facility & 2.09 & 3.42 & -0.34 \\
\hline $\begin{array}{l}\text { The new school offered reduced fees for my } \\
\text { child/children }\end{array}$ & 1.60 & 3.41 & -0.50 \\
\hline $\begin{array}{l}\text { The new school had a manageable } \\
\text { student-teacher ratio }\end{array}$ & 4.20 & 5.77 & -0.39 \\
\hline $\begin{array}{l}\text { In the previous school I was not teaching at } \\
\text { the right level of school phase according to } \\
\text { my qualification and/or experience }\end{array}$ & 3.53 & 4.57 & -0.26 \\
\hline $\begin{array}{l}\text { My spouse/family moved to another } \\
\text { address or city }\end{array}$ & 3.58 & 3.42 & 0.04 \\
\hline $\begin{array}{l}\text { The previous school offered no chances of } \\
\text { job promotion }\end{array}$ & 2.89 & 4.99 & -0.50 \\
\hline $\begin{array}{l}\text { I fell out with the school leadership and } \\
\text { management bodies }\end{array}$ & 2.44 & 3.99 & -0.41 \\
\hline $\begin{array}{l}\text { The previous school was in an area of high } \\
\text { poverty }\end{array}$ & 3.67 & 3.36 & 0.08 \\
\hline $\begin{array}{l}\text { The previous school provided very limited } \\
\text { teaching resources }\end{array}$ & 3.53 & 4.72 & -0.31 \\
\hline $\begin{array}{c}\text { The previous school was closed by the } \\
\text { management authorities }\end{array}$ & 1.52 & 3.02 & -0.43 \\
\hline $\begin{array}{c}\text { The previous school environment was not } \\
\text { intellectually stimulating }\end{array}$ & 2.69 & 4.18 & -0.40 \\
\hline $\begin{array}{c}\text { The previous school did not nominate me } \\
\text { for a professional development } \\
\text { opportunity }\end{array}$ & 2.88 & 4.53 & -0.42 \\
\hline
\end{tabular}

In Table 8, highlighted average scores and effect sizes show noteworthy differences among public and private school teachers in their reasons to change school. Teachers in private schools changed schools due to workload and dissatisfaction with salary. However, teachers in public schools reported a higher average in reasons of changing school due to difficulties in commuting to school and location of school in the regions of high poverty. 
Change in family status and transfer by the orders of the education department are the main reasons for public school teachers to have changed school. Intellectually stimulating work environment and lack of professional development opportunities are important reasons for changing schools for private school teachers. Private school teachers offered longer contracts of teaching service, which can be an attractive incentive for teacher retention.

\section{Conclusions}

The sample achieved in this study suggests that teacher mobility is slightly higher in public schools than in private schools in Pakistan. This follows successful implementation of a rationalisation policy to improve teacher retention and fair teacher composition in urban and rural schools. It is perhaps the implementation of rationalisation and transfer policy which has made teacher mobility volatile in public schools. Teachers who changed school in their early career, with an average of two years teaching experience, gained higher salary benefits by changing schools compared to teachers with an average of 14 years of teaching experience, who never changed schools. It is noteworthy that the proportion of private school teachers in the sample (46\%) is lower than public school teachers (51\%). In other words, more teachers from the public sector responded to the survey than from the private sector. In comparison with early career teachers, experienced teachers who never changed school had lower salaries but higher satisfaction with life in general and with school as their workplace. Teachers currently in urban areas tend to be more mobile than teachers in rural areas which might suggest that the direction of mobility is toward schools in urban locations. If so, transfer policy needs to introduce measures where rural to urban teacher mobility can be fairly addressed.

Overall, teacher salary does not seem to be the determining factor for teacher retention. Satisfaction with work environment seems to play an important role in teacher retention. Satisfaction with work environment and school conditions can make a teaching job more attractive and is likely to increase teacher retention in school and in profession. These are areas of investment for strengthening the infrastructure of public schools to make them more attractive for teachers to join the profession and retain on long-term basis. Working conditions in schools need more development initiatives where public school intake of children is a mix of pupils from different socioeconomic backgrounds. Public schools in the regions of high poverty and rural areas need additional resources and support provision to overcome the needs of disadvantaged students in schools. Another area of policy and provisions could be to tackle teachers feeling isolated from developing regions and opportunities. Perhaps, schools connected through digital technologies can make a difference in this regard. Better transport facilities, road links, and safe travel routes have been repeatedly suggested for improvement in other areas of development such as increasing school enrolment and attendance, especially for girls. These improvement for development in infrastructure can also improve teacher mobility patterns toward harder areas making schools in rural areas attractive job places.

Implications of these findings are also on public education policies of rationalization and teacher transfer where the intention to overcome corruption and compositional disparities in teacher workforce are likely to impact teachers' lack of satisfaction with their job. The lesson for private schools is that longer and sustainable teaching contracts can be an attractive incentive for teacher retention and long-term commitment to a school. If private schools can offer some reliable pension schemes, then teachers' retention in a school can possibly be for a longer time.

The logistic regression model could only explain $62 \%$ of the differences between those who changed school and those who did not. This suggests that there are other factors that are not accounted for that could explain these differences. A bigger and better database is needed for more conclusive evidence.

It is useful for researchers that the Punjab government has successfully digitised data on public school teachers. This information is important for the purpose of fair decisions on teacher recruitment, deployment, and transfer. We hope that the data systems can include 
information on private school teachers for observing disparities and finding potential for workforce cooperation in the two parallel systems. Administrative data have great value for research informed and evidence-based policy. Therefore, we would encourage the School Education Department to develop a reliable infrastructure for utilising administrative data and implement a data-sharing policy which can benefit the education department and also contribute to academic research for a high-quality evidence.

Author Contributions: Conceptualization, N.S. and S.S.; Methodology, N.S. and S.S.; Software, Bristol Online Survey, SPSS version 21.; Formal analysis, N.S. and S.S.; Investigation, S.S. and N.S.; Writing - original draft preparation, N.S. and S.S. All authors have read and agreed to the published version of the manuscript.

Funding: No funding acquisition.

Institutional Review Board Statement: This study was conducted according to the guidelines of British Education Research Association. The project was formally approved by the University of Education, Lahore, Ethics Review Board.

Informed Consent Statement: All participants volunteered to take part in the anonymous survey and consented to use the information for the research purpose.

Data Availability Statement: The anonymised data files can be accessed by contacting the authors.

Acknowledgments: We thank all the teachers who volunteered to take part in the anonymous survey and consented to use their reported information for the research propose.

Conflicts of Interest: No conflict of interest.

\section{References}

1. School Education Department (SED). Simple, Convenient and Efficient! E-Transfer Public School Teachers 2019; Punjab Information Technology Board: Punjab, Pakistan, 2019. Available online: Punjab.gov.pk (accessed on 24 February 2021).

2. Siddiqui, N. Socio-economic segregation of disadvantaged children between schools in Pakistan: Comparing the state and private sector. Educ. Stud. 2017, 43, 391-409. [CrossRef]

3. Alderman, H.; Orazem, P.F.; Paterno, E.M. School Quality, School Cost, and the Public/Private School Choices of Low-Income Households in Pakistan. J. Hum. Resour. 2001, 36, 304. [CrossRef]

4. Andrabi, T.; Das, J. The Rise of Private Schooling in Pakistan: Catering to the Urban Elite or Education the Rural Poor? The Study of World Bank: Harvard, MA, USA, 2002.

5. Bari, F.; Raza, R.; Aslam, M.; Khan, B.; Maqsood, N. An Investigation into Teacher Recruitment and Retention in Punjab; IDEASInstitute of Development and Economic Alternatives: Punjab, Pakistan, 2013.

6. Siddiqui, N.; Gorard, S. Comparing government and private schools in Pakistan: The way forward for universal education. Int. J. Educ. Res. 2017, 82, 159-169. [CrossRef]

7. SABER Teachers of Punjab Pakistan. Systems Approach for Better Education Results (SABER): World Bank; SABER Teachers Pakistan Punjab Country Report 2018; SABER Teachers of Punjab Pakistan: Punjab, Pakistan, 2018. Available online: Worldbank.org (accessed on 28 January 2021).

8. Hair, N.L.; Hanson, J.L.; Wolfe, B.L.; Pollak, S.D. Association of child poverty, brain development, and academic achievement. JAMA Pediatrics 2015, 169, 822-829. [CrossRef] [PubMed]

9. Shaukat, S.; Vishnumolakala, V.R.; Al Bustami, G. The impact of teachers' characteristics on their self-efficacy and job satisfaction: A perspective from teachers engaging students with disabilities. J. Res. Spec. Educ. Needs 2019, 19, 68-76. [CrossRef]

10. Ingersoll, R.M. Teacher Turnover and Teacher Shortages: An Organizational Analysis. Am. Educ. Res. J. 2001, 38, 499-534. [CrossRef]

11. Toropova, A.; Myrberg, E.; Johansson, S. Teacher job satisfaction: The importance of school working conditions and teacher characteristics. Educ. Rev. 2021, 73, 71-97. [CrossRef]

12. Falch, T. Teacher Mobility Responses to Wage Changes: Evidence from a Quasi-Natural Experiment. Am. Econ. Rev. 2011, 101, 460-465. [CrossRef]

13. Asadullah, M.N. Returns to private and public education in Bangladesh and Pakistan: A comparative analysis. J. Asian Econ. 2009, 20, 77-86. [CrossRef]

14. Allen, R.; Sims, S. The Teacher Gaps; Routledge: London, UK, 2018.

15. Khan, T. Teacher Job Satisfaction and Incentive. A Case Study of Pakistan, DFID, Microsoft Word-TMIPa-kistanELDIS.doc. 2005. Available online: Publishing.service.gov.uk (accessed on 5 January 2021).

16. Hanushek, E.A.; Kain, J.F.; Rivkin, S.G. Why Public Schools Lose Teachers. J. Hum. Resour. 2004, 39, 326. [CrossRef]

17. Feng, L. Teacher Placement, Mobility, and Occupational Choices after Teaching. Educ. Econ. 2014, 22, 1-24. [CrossRef] 
18. Prost, C. Teacher Mobility: Can Financial Incentives Help Disadvantaged Schools to Retain Their Teachers? Ann. Econ. Stat. 2013, 171. [CrossRef]

19. Neilson, C.; Bobba, M.; Ederer, T.; Leon-Ciliotta, G.; Nieddu, M. Teacher Compensation and Structural Inequality: Evidence from Centralized Teacher School Choice in Peru. 2021. Available online: http:/ /arks.princeton.edu/ark:/88435/dsp01nv935592w (accessed on 24 April 2021).

20. Clotfelter, C.; Glennie, E.; Ladd, H.; Vigdor, J. Would higher salaries keep teachers in high-poverty schools? Evidence from a policy intervention in North Carolina. J. Public Econ. 2008, 92, 1352-1370. [CrossRef]

21. Weiqi, C. The structure of secondary school teacher job satisfaction and its relationship with attrition and work enthusiasm. Chin. Educ. Soc. 2007, 40, 17-31. [CrossRef]

22. Imazeki, J. Teacher salaries and teacher attrition. Econ. Educ. Rev. 2005, 24, 431-449. [CrossRef]

23. Jackson, C.K. Student demographics, teacher sorting, and teacher quality: Evidence from the end of school desegregation. J. Labor Econ. 2009, 27, 213-256. [CrossRef]

24. Sharma, R.D.; Jyoti, J. Job satisfaction among school teachers. IIMB Manag. Rev. 2006, 18, 349-363.

25. Kirabo, J.C.; Bruegmann, E. Teaching Students and Teaching Each Other: The Importance of Peer Learning for Teachers. Am. Econ. J. Appl. Econ. 2009, 1, 85-108.

26. Rehmani, A. Teacher education in Pakistan with particular reference to teachers' conceptions of teaching. Qual. Educ. Teach. Leadersh. Challeng. Times 2006, 2, 495-524. Available online: http:/ / ecommons.aku.edu/pakistan_ied_pdck/134 (accessed on 13 July 2021).

27. Delors, J. Learning: The Treasure Within; UNESCO: Paris, France, 1996.

28. Darling-Hammond, L. Powerful Teacher Education: Lessons from Exemplary Programs; John Wiley and Sons, Inc.: San Francisco, CA, USA, 2006.

29. Bradburb, M.B.; Gilford, D.M. (Eds.) A Framework for International Comparative Studies in Education; National Academy Press: Washington, DC, USA, 1990.

30. Halai, A. Equality or Equity: Gender Awareness Issues in Secondary Schools in Pakistan. Equality or Equity: Gender Awareness Issues in Secondary Schools in Pa by Anjum Halai. 2011. Available online: https://doi.org/10.1016/j.ijedudev.2010.06.012 (accessed on 14 July 2021).

31. Naviwala, N. Pakistan Education Crisis: A Real Story. Woodrow Wilson International Center for Scholars. One Woodrow Wilson Plaza. 2016. Available online: https://www.wilsoncenter.org/sites/default/files/pakistanseducationcrisistherealstory2.pdf (accessed on 13 January 2020).

32. Iqbal, H.M. Teachers' content knowledge and pedagogical competence: Issues for teacher status in Pakistan. In Teacher Status: A Symposium; Halai, A., Ed.; 2007; pp. 42-65. Available online: http:/ / ecommons.aku.edu/cgi/viewcontent.cgi?article=1006 \&context=books (accessed on 12 January 2020).

33. Global Partnership for Education (GPE). Technology Boost and Education Reforms in Remote Areas: Pakistan. GPE Transforming Education. 2020. Available online: https://www.globalpartnership.org/results/stories-of-change/pakistan-technology-boostseducation-reform-remote-areas (accessed on 13 January 2020).

34. Chughati, F.D.; Perveen, U. A study of teachers workload and job satisfaction in public And private schools at secondary level in Lahore city Pakistan. Asian J. Soc. Sci. Humanit. 2013, 2, 202-214.

35. Rivkin, S.G.; Hanushek, E.A.; Kain, J.F. Teachers, Schools, and Academic Achievement. Econometrica 2005, 73, 417-458. [CrossRef]

36. Barbieri, G.; Rossetti, C.; Sestito, P. The Determinants of Teacher Mobility. Evidence from a Panel of Italian Teachers; Ministry of Education: Wellington, DC, USA, 2010. Available online: https://www.bancaditalia.it/pubblicazioni/temi-discussione/2010/2 010-0761/en_tema_761.pdf (accessed on 13 January 2020).

37. Bradley, S.; Green, C.; Leeves, G. The Role of Pecuniary and Non-Pecuniary Factors in Teacher Turnover and Mobility Decisions; Lancaster University Management School, Economics Department: Lancaster, UK, 2006.

38. Transfer Policy. Government of the Punjab. School Education Department. 2013. Available online: https://schools.punjab.gov. pk/system/files/TransferPolicy-2013_0.pdf (accessed on 17 April 2021).

39. Dawn. Female Teachers Protest against FDE's Repatriation Orders. 14 January 2021. Available online: https://www.dawn.com/ news /1601394 (accessed on 17 April 2021).

40. The News Police Make Use of Water Cannons to Thwart Teachers' Protest. 8 September 2020. Available online: https://www. thenews.com.pk/print/711639-female-teachers-protest-transfer-to-remote-areas (accessed on 20 March 2021).

41. Farooq, R.A. Education System of Pakistan: Issues and Problems; Asia Society for Promotion of Innovation and Reforms in Education: Islamabad, Pakistan, 1993; pp. 10-20.

42. Bregman, J.; Muhammad, N. Primary and Secondary Education Structural Issues; Jan Publications: Islamabad, Pakistan, 1998; pp. 23-31.

43. Andrabi, T.; Das, J.; Khwaja, A.; Vishwanath, T.; Zajonc, T. Pakistan, Learning and Educational Achievements in Punjab Schools (LEAPS): Insights to Inform the Education Policy Debate; World Bank: Washington, DC, USA, 2007.

44. Jerrim, J.; Sims, S. When is high workload bad for teacher wellbeing? Accounting for the non-linear contribution of specific teaching tasks. Teach. Teach. Educ. 2021, 105, 103395. [CrossRef]

45. Gorard, S. How to Make Sense of Statistics; Sage: London, UK, 2021. 